\title{
Placental vascular pathology and increased thrombin generation as mechanisms of disease in obstetrical syndromes
}

Obstetrical complications including preeclampsia, fetal growth restriction, preterm labor, preterm prelabor rupture of membranes and fetal demise are all the clinical endpoint of several underlying mechanisms (i.e. infection inflammation, thrombosis, endocrine disorder, immunologic rejection, genetic, and environmental), therefore, they may be regarded as syndromes. Placental vascular pathology and increased thrombin generation were reported in all of these obstetrical syndromes. Moreover, elevated concentrations of thrombin-anti-thrombin III complexes and changes in the coagulation as well as anticoagulation factors can be detected in the maternal circulation prior to the clinical development of the disease in some of these syndromes. In this review, we will assess the changes in the hemostatic system during normal and complicated pregnancy in maternal blood, maternal-fetal interface and amniotic fluid, and describe the contribution of thrombosis and vascular pathology to the development of the great obstetrical syndromes. 
1 Placental Vascular Pathology and Increased Thrombin Generation as Mechanisms of 2 Disease In Obstetrical Syndromes

3 Salvatore Andrea Mastrolia ${ }^{1,2}$, Moshe Mazor ${ }^{2}$, Giuseppe Loverro', Vered Klaitman ${ }^{2}$, and Offer 4 Erez $^{2}$

$5{ }^{1}$ Department of Obstetrics and Gynecology, Azienda Ospedaliero-Universitaria Policlinico di 6 Bari, School of Medicine, University of Bari “Aldo Moro", Bari, Italy

$7{ }^{2}$ Obstetrics and Gynecology, Soroka University Medical Center, School of Medicine, Ben Gurion

8 University of the Negev, Beer Sheva, Israel

9 Corresponding author

10 Offer Erez M.D.

11 Acting director Maternal Fetal Medicine Unit

12 Department of Obstetrics and Gynecology

13 Soroka University Medical Center

14 School of Medicine, Faculty of Health Sciences

15 Ben Gurion University of the Negev

16 P.O.Box 151,

17 Beer Sheva 84101

18 Israel

19 erezof@bgu.ac.il

\section{1. Introduction}

21 Obstetrical complications including preeclampsia, fetal growth restriction, preterm labor, preterm 22 prelabor rupture of membranes and fetal demise are all the clinical endpoint of several underlying 23 mechanisms (i.e. infection inflammation, thrombosis, endocrine disorder, immunologic rejection, 24 genetic, and environmental), therefore, they may be regarded as syndromes. In this review, we 25 will assess the changes in the hemostatic system during normal and complicated pregnancy in 26 maternal blood, maternal-fetal interface and amniotic fluid, and describe the contribution of 27 thrombosis and vascular pathology to the development of the great obstetrical syndromes.

\section{2. What are the great obstetrical syndromes?}


29 The major obstetrical complications including preeclampsia, intrauterine growth restriction 30 (IUGR), preterm labor (PTL), preterm prelabor rupture of membranes (PROM), fetal demise, and 31 recurrent abortions are all syndromes, also defined as "great obstetrical syndromes". As reported 32 in The Oxford Medical Dictionary a syndrome is 'a combination of symptoms and/or signs that 33 form a distinct clinical picture indicative of a particular disorder'. Hence, they represent the 34 clinical manifestation of many possible underlying mechanisms of disease ${ }^{1}$.

35 Key features of these syndromes $a^{2}$ : multiple etiologies; long preclinical stage; frequent fetal 36 involvement; clinical manifestations which are often adaptive in nature; and predisposition to a 37 particular syndrome is influenced by gene-environment interaction and/or complex gene-gene 38 interactions involving maternal and/or fetal genotypes. These mechanisms of disease were 39 identified and reported in all the obstetrical complications listed above. This review is focused on 40 the role of thrombosis and vascular pathology of the placenta in these syndromes.

41 3. What are the changes in the coagulation system during normal pregnancy?

42 In term of the coagulation and hemostatic systems there are several major compartments: the 43 maternal circulation, the fetal maternal interface (the placenta, and membranes), amniotic fluid 44 and the fetus that each has a specific behavior during gestation. The changes in the coagulation 45 system during gestation are considered to be adaptive mechanisms and are aimed to: 1) the 46 prevention of bleeding at the time of trophoblast implantation and the delivery of the fetus; 2) 47 allow the laminar flow and the intervillous space; and 3) seal amniotic fluid leak and reduce 48 obstetrical bleeding ${ }^{3-7}$. Of interest, the fetus is somewhat less involved and its coagulation system 49 develops during gestation, and this subject is beyond the scope of this review.

50 Indeed, normal pregnancy has been associated with excessive maternal thrombin generation ${ }^{3,8}$ 51 and a tendency for platelets to aggregate in response to agonists ${ }^{9,10}$. Pregnancy is accompanied by 522 to 3 -fold increase in fibrinogen concentrations and $20 \%$ to $1000 \%$ increase in factors VII, VIII, 53 IX, X, and XII, all of which peak at term ${ }^{11}$. The concentrations of vWF increase up to $400 \%$ by 54 term $^{11}$. By contrast, those of pro-thrombin and factor $\mathrm{V}$ remain unchanged while the 55 concentrations of factors XIII and XI decline modestly ${ }^{12}$. Indeed there is evidence of chronic low56 level thrombin and fibrin generation throughout normal pregnancy as indicated by enhanced 57 concentrations of pro-thrombin fragment 1.2, thrombin-antithrombin (TAT) III complexes, and 58 soluble fibrin polymers ${ }^{13}$. Free protein $\mathrm{S}$ concentration declines significantly (up to 55\%) during 59 pregnancy due to increased circulating complement 4B-binding protein its molecular carrier. 60 Protein S nadir at delivery and this reduction is exacerbated by cesarean delivery and infection ${ }^{11}$, $61{ }^{12}$. As a consequence, pregnancy is associated with an increase in resistance to activated protein 
$62 \mathrm{C}^{12,13}$. The concentrations of PAI-1 increase by 3 to 4-folds during pregnancy while plasma PAI-2

63 values, which are negligible before pregnancy reach concentrations of $160 \mathrm{mg} / \mathrm{L}$ at delivery ${ }^{11}$.

64 Thus, pregnancy is associated with increased clotting potential, as well as decreased

65 anticoagulant properties, and fibrinolysis ${ }^{14}$. Therefore, it can be defined as a prothrombotic state.

66 One of the most important mediators of the hypercoagulable state of normal pregnancy is tissue

67 factor (TF). Indeed, there is a substantial increase in $\mathrm{TF}$ concentrations in the decidua and

68 myometrium ${ }^{15-18}$, preventing placental abruption since this leads to an increase in the efficiency of

69 clotting function $^{14}$. The placenta is a source of TF, since trophoblast cells constitutively express it,

70 behaving as activated endothelium, and leading to a condition of procoagulant state that, if not

71 controlled by anticoagulant mechanisms, predisposes to thrombotic complications ${ }^{15}$. The

72 principal anticoagulant mechanism inhibiting TF activation pathway is tissue factor pathway

73 inhibitor (TFPI), which mRNA is highly expressed in the macrophages in the villi in term 74 placenta $^{19}$.

75 Similarly, high TF concentrations have been detected in the fetal membranes (mainly the amnion)

76 and amniotic fluid ${ }^{7,20-23}$. TFPI has been found in amniotic fluid as well ${ }^{20}$, but it is not clear if the

77 presence of TF and its natural inhibitor is related to coagulation per se or is somehow connected

78 with embryonic development ${ }^{24}$.

79 In contrast to the changes detected in the amniotic fluid and the decidua, the median maternal

80 plasma immunoreactive TF concentration of normal pregnant women do not differ significantly

81 from that of non-pregnant patients ${ }^{3,25}$. However, labor at term increases significantly the maternal

82 plasma immunoreactive TF concentration in comparison to the non-pregnant state ${ }^{20}$. In addition

83 to the changes in TF, normal pregnancy is associated with increased thrombin generation ${ }^{3,8}$, as

84 determined by the elevation of maternal concentrations of fibrinopeptide A, prothrombin

85 fragments (PF) 1 and 2, and thrombin-antithrombin (TAT) III complexes ${ }^{7,26-28}$. The concentration

86 of these complexes further increases during and after normal parturition ${ }^{27,29}$, and subsequently

87 decreases during the puerperium ${ }^{27,29}$.

88 4. What are the changes in the hemostatic system associated with the great obstetrical 89 syndromes?

90 The great obstetrical syndromes are associated with changes in the hemostatic and vascular

91 systems in the compartments mentioned above: 1) the maternal circulation; 2) the feto-maternal

92 interface of placenta and membranes; 3 ) and the amniotic fluid.

\section{4.1 Changes in the hemostatic system of women with obstetrical syndromes.}


94 The involvement of the hemostatic system in the pathophysiology of these obstetrical syndromes

95 is becoming more and more apparent. Indeed, increased thrombin generation is reported in the

96 maternal circulation of women with preeclampsia ${ }^{30-34}$, IUGR $^{30-32,35,36}$, fetal demise $\mathrm{S}^{37}, \mathrm{PTL}^{8,37,38}$ and 97 preterm PROM $^{8,37,39}$.

98 There are several possible explanations for the increased thrombin generation in these patients: 1)

99 increased activation of coagulation cascade in the maternal circulation due to pathological 100 processes including bleeding or inflammation; and 2) depletion of anticoagulation proteins that 101 subsequently leads to increased thrombin generation (Table 1).

102 4.1.1 Increased activation of the coagulation cascade and thrombin generation in the 103 maternal circulation in patients with pregnancy complications

104 All the obstetrical syndromes including preeclampsia ${ }^{30-34,40,41}, \mathrm{IUGR}^{31,32,35}$, 36, fetal demise ${ }^{37}, \mathrm{PTL}^{8}$, $105{ }^{38}$ and preterm PROM $^{8,37,39}$ are associated with a higher maternal thrombin generation than a 106 normal pregnancy. These may be of clinical implication since in women with preterm labor, 107 elevated maternal plasma TAT III complexes concentration was associated with a higher chance 108 to deliver within $<7$ days from admission ${ }^{37}$ (Fig. 1). To further understand how does thrombin 109 affect the duration of pregnancy and the clinical phenotype of patients with the obstetrical 110 syndromes we need to consider what are the mechanisms leading to thrombin generation and how 111 it affects the feto-maternal unit.

112 Increased thrombin generation can result from the following underlying mechanisms: 1) decidual 113 hemorrhage that leads to a retro-placental clot formation ${ }^{42}$; 2) intra-amniotic 114 infection/inflammation which can induce decidual bleeding and sub-clinical abruption ${ }^{43}$, as well 115 as increased intra-amniotic TAT complexes $^{37}$; and 3) an increased maternal systemic 116 inflammatory response ${ }^{44}$ that may activate the extrinsic pathway of coagulation due to the 117 expression and release of TF by activated monocytes ${ }^{45}$.

118 Thrombin affects many systems including also the following: 1) stimulation of decidual cell 119 secretion of matrix metalloproteinase (MMP) (i.e. MMP-1 and MMP-3) that can degrade the 120 extracellular matrix of the chorioamniotic membranes ${ }^{46,47}$ (as in preterm PROM); 2) myometrial 121 activation and uterine contractions generation that may lead to preterm labor with or without 122 rupture of membranes and a subsequent preterm delivery ${ }^{38,48,49}$; and 3) thrombin has an inhibitory 123 effect on the production of TFPI by endothelial cells ${ }^{50}$, and the increased thrombin generation 124 observed in patients with PTL may be associated with a concomitant reduction in TFPI 125 production by the maternal vascular endothelium (the depletion of anticoagulant proteins will be 126 discussed in the following section of this review). 
127 There is evidence to support that the extrinsic pathway of coagulation is activated in many of

128 these pregnancy complications and it is the source of the increased thrombin generation ${ }^{51}$. Indeed,

129 increased immunoreactive TF concentrations were reported in women with preeclampsia and

130 those with preterm $\mathrm{PROM}^{52}$. Moreover, the contribution of preeclampsia to elevated maternal

131 immunoreactive TF persisted also among patients with fetal demise, while those with fetal death

132 who were normotensive did not have higher median TF concentration than normal pregnant

133 women. Moreover, the median TF concentration of patients with preeclampsia was also higher

134 than in patients with fetal demise without hypertension. These findings are consistent with

135 previous studies ${ }^{3,53}$, suggesting that elevated TF immunoreactivity and activity may be associated

136 with the pathophysiologic process leading to preeclampsia, rather than being a consequence of

137 the fetal death.

138 In some of the obstetrical syndromes there was elevated TF activity in the maternal circulation

139 without a concomitant increase in the plasma concentration of this factor. This was the case

140 among patients with a small for gestational age (SGA) neonate and those with preterm labor ${ }^{31,54}$

141 (Table 1). This suggests that the increased TF activity among patients with PTL as well as those

142 with an SGA neonate, contributes to a higher generation of factor Xa that, along with the

143 physiologic increase in the maternal plasma concentrations of factor VII and factor X during

144 gestation ${ }^{11,55-57}$, may be the underlying mechanism leading to the increased thrombin generation

145 reported these syndromes.

146 The differences between PTL and preterm PROM in term of maternal plasma TF concentration

147 and activity may derive from the specific component of the common pathway of parturition,

148 which is activated in each obstetrical syndrome ${ }^{58}$. While preterm PROM is associated with the

149 activation of the decidua and the membranes, myometrial activation is the major component of

150 preterm labor with intact membranes ${ }^{58}$. This is relevant because the decidua and the membranes

151 have a high TF concentration ${ }^{17,18,59}$.

152 In summary, the evidence brought herein suggests that increased thrombin generation in patients

153 with the great obstetrical syndromes may reflect the activation of the coagulation cascade mainly

154 through the extrinsic arm. This activation can be attributed to various underlying mechanisms.

\section{4.1.2 Depleted or insufficient anticoagulant proteins concentration}

156 In the normal state there is a delicate balance between the proteins activating/participating the

157 coagulation cascade and their inhibitors. Increased thrombin generation may result, as we

158 presented above, from activation of the coagulation cascade due to higher concentrations or

159 activities of the proteins included in the coagulation cascade. However, thrombin generation can

160 also result from insufficient concentration or activity of anticoagulation proteins. 
161 Tissue factor pathway inhibitor (TFPI), a glycoprotein comprising of three Kunitz domain ${ }^{60}$ that

162 are specific inhibitors of trypsin-like proteinases ${ }^{61}$, is the main inhibitor of the extrinsic pathway

163 of coagulation. TFPI inhibits thrombin generation through the inactivation of activated factor X

164 and the factor VIIa/TF complex ${ }^{60,62}$. The mean maternal plasma concentrations of total TFPI

165 increases during the first half of pregnancy, remains relatively constant in the second half ${ }^{63}$ and

166 decreases during labor ${ }^{20}$. There are two types of TFPI: 1) TFPI-1 is the more prevalent form in

167 the non-pregnant state in the maternal circulation and can also be found in the fetal blood,

168 platelets, endothelial cells and other organs ${ }^{19,64}$; and 2) TFPI-2- the major form of TFPI in the

169 placenta ${ }^{65-68}$, also known as Placental Protein $5(\mathrm{PP} 5)^{69,70}$. During pregnancy, the maternal plasma

170 concentration of TFPI-2 increases gradually, reaches a plateau at 36 weeks and subsides after

171 delivery $^{71-74}$.

172 The overall balance between the concentration and activity of the coagulation factors and the

173 anti-coagulation proteins is one of the determining factors of thrombin generation. In the normal

174 state, the immunoreactive concentrations of TFPI in the plasma are 500 to 1000 times higher than

175 that of $\mathrm{TF}^{75}$, suggesting that an excess of anti-coagulant proteins closely controls the coagulation

176 cascade activity. The median maternal plasma TFPI concentration increases during

177 preeclampsia ${ }^{53,76}$, which is associated with an exaggerated maternal systemic inflammatory

178 response. However, the increase in the median maternal TF plasma concentration is such that the

179 overall balance between TF and its inhibitor is affected leading to increased thrombin generation

180 in this syndrome. In contrast to preeclampsia, maternal plasma TFPI concentration decreases in

181 patients with $\mathrm{PTL}^{52}$ and preterm $\mathrm{PROM}^{77}$ regardless to the presence of intra-amniotic

182 infection/inflammation, as well as in women with fetal demise ${ }^{54}$, and does not change in mothers

183 with SGA fetuses ${ }^{53}$. Overall these findings suggest that the increased thrombin generation

184 observed among these patients may derive not only from an increased activation of the

185 hemostatic system, but also from insufficient anti-coagulation, as reflected by the lower TFPI

186 concentrations (Fig. 2).

187 A possible explanation of the lower maternal plasma concentration observed in some of the

188 obstetrical syndromes may be that during these syndromes there is a reduction in the placental

189 production of $\mathrm{TFPI}^{65,66,69,76}$ (mainly TFPI-2), contributing to the low maternal plasma

190 concentrations detected in patients with PTL, in addition to the thrombin inhibitory effect to TFPI

191 expression on endothelial cells, as above mentioned. Indeed, patients with vascular complications

192 of pregnancy (preeclampsia, eclampsia, placental abruption, fetal growth restriction, and fetal 
193 demise) have a lower placental concentration of total TFPI, and TFPI mRNA expression than in 194 women with normal pregnancies ${ }^{78,79}$.

195 Other proteins implicated in the inhibitory control of the coagulation cascade are protein S, 196 protein $\mathrm{C}$ and protein $\mathrm{Z}$. Protein $\mathrm{S}$ is a cofactor to protein $\mathrm{C}$ in the inactivation of factors 197 Va and VIIIa. This protein exists in two forms: a free form and a complex form bound 198 to complement protein C4b-binding protein (C4BP). Only the free form is active ${ }^{80}$. Protein S also 199 acts as a TFPI cofactor, in the presence of weak pro-coagulant stimuli, by enhancing the 200 interaction of TFPI with factor Xa while using $\mathrm{Ca} 2+$ and phospholipids in the process ${ }^{81}$ without 201 increasing inhibition of factor VIIa-TF by TFPI ${ }^{82}$. During pregnancy there is a physiologic 202 change in the relationship between the bound and the free forms of protein $\mathrm{S}$ in the maternal 203 plasma. The increase in C4BP during gestation reduces free protein S concentration in up to 55\% 204 of its value out of pregnant state, reaching its nadir at delivery. Of interest, cesarean delivery and 205 infection exacerbate the reduction in free protein $\mathrm{S}$ concentrations ${ }^{11,83}$. Moreover, a functional 206 protein $\mathrm{S}$ deficiency can explain a poor response to activated protein $\mathrm{C}^{84}$.

207 The association between the alteration of concentration and function of protein $\mathrm{S}$ and protein $\mathrm{C}$ in

208 the great obstetrical syndromes is not completely clear. The evidence regarding the association of 209 protein $\mathrm{S}$ and protein $\mathrm{C}$ deficiency and preeclampsia is controversial ${ }^{85,86}$.

210 While some reported an association between protein S deficiency and an increased risk for this 211 syndrome (especially for early onset preeclampsia) $)^{85}$ others could not demonstrate this effect ${ }^{86}$. 212 There is some evidence regarding the relation of protein S deficiency and increased risk of 213 stillbirth ${ }^{87}$ and mid-trimester IUGR ${ }^{88}$. An increased risk of stillbirth has been reported in patients 214 with protein S deficiency while the risk was not significantly increased in cases of protein C 215 deficiency $^{87}$, and Kupferminc et $\mathrm{al}^{88}$ found that protein $\mathrm{S}$, but not protein $\mathrm{C}$ deficiency, was 216 significantly associated with severe mid-trimester IUGR.

217 Protein Z, in complex with protein Z-dependent protease inhibitor (ZPI) (Fig. 3) ${ }^{89-91}$, acts as a 218 physiologic inhibitor of activation of prothrombin by factor $\mathrm{Xa}$. Protein $\mathrm{Z}$ is a vitamin 219 K-dependent plasma glycoprotein ${ }^{92}$ that is an essential cofactor for ZPI activity. In the absence of 220 protein $\mathrm{Z}$, the activity of ZPI is reduced by more than 1000 -fold $^{91}$. Normal pregnancy is 221 characterized by an increased plasma concentration of protein $Z^{93}$, probably as a compensation 222 for the increase of factor $\mathrm{X}$ concentration. Women with preterm labor without intra-amniotic 223 infection or inflammation and those with vaginal bleeding who delivered preterm had a lower 224 median maternal plasma protein $\mathrm{Z}$ concentration than women with a normal pregnancy and those 225 with vaginal bleeding who delivered at term ${ }^{94}$. The changes of protein $\mathrm{Z}$ concentrations in other 226 pregnancy complications are controversial. Some demonstrated that the median plasma 
227 concentration of protein $\mathrm{Z}$ in patients with preeclampsia, IUGR, and late fetal death were not

228 significantly different than that of patients with a normal pregnancy ${ }^{95}$. Others reported lower

229 median maternal plasma protein $\mathrm{Z}$ concentrations in women with preeclampsia or pyelonephritis

230 and higher proportion of protein $\mathrm{Z}$ deficiency (defined as protein $\mathrm{Z}$ plasma concentration below

231 the $5^{\text {th }}$ percentile) in patients with preeclampsia or fetal demise than in those with a normal

232 pregnancy $^{96}$. Moreover, increased maternal plasma anti-protein $\mathrm{Z}$ antibodies concentrations were

233 associated with SGA neonates, fetal demise and preeclampsia.

234 The information presented above suggest that it is not only the concentration of one coagulation

235 factor or anticoagulation protein, but rather the overall balance between the coagulation factors

236 and their inhibitors that increases thrombin generation in the great obstetrical syndromes. Indeed,

237 although preterm labor was not associated with a significant change in the median maternal

238 plasma TF concentration, the TFPI/TF ratio of these patients was lower than that of normal 239 pregnant women, mainly due to decreased TFPI concentrations.

240 This observation was also reported in patients with preterm $\operatorname{PROM}^{77}$, and those with

241 preeclampsia ${ }^{53}$. The lower TFPI/TF ratio in patients with preeclampsia occurs despite the increase

242 in the median maternal plasma TFPI concentration observed in these patients. This suggests that

243 the balance between TF and its natural inhibitor may better reflect the overall activity of the TF

244 pathway of coagulation, than the individual concentrations of TF or TFPI.

245 Collectively, these observations suggest that our attention should be focused not only on the

246 coagulation protein but also on their inhibitors since an imbalance between them may contribute

247 to increased thrombin generation leading to the onset of the great obstetrical syndromes. 
$248 \quad 4.2$ Changes in the feto-maternal interface

249 Normal placental development and the establishment of an adequate feto-maternal circulation are

250 key points for a successful pregnancy. The networks of the placental vascular tree either on the

251 maternal or fetal side are dynamic structures that can be substantially altered in cases of abnormal

252 placentation and trophoblast invasion. The human trophoblast has properties of endothelial cells

253 and can regulate the degree of activation of the coagulation cascade in the intervillous space ${ }^{97,98}$.

254 The villous trophoblasts express heparin sulfate, protein $\mathrm{C}$ and protein $\mathrm{Z}$ on their surface that

255 serve as anticoagulant that sustain laminar blood flow through the intervillous space. On the other

256 hand, unlike the endothelium of other organs, the trophoblast constantly presents the active

257 placental isoform of TF on its surface ${ }^{98-101}$. This isoform has a higher affinity for factor VIIa ${ }^{102}$,

258 which may lead to increased activation of the coagulation cascade. One of the leading

259 pathological processes observed in all these syndromes is thrombosis and vascular abnormality of

260 the placenta at the maternal-fetal interface. The incidence of these pathological processes varies

261 among the different syndromes being more prevalent in preeclampsia, IUGR, and fetal demise

262 than in PTL and preterm PROM ${ }^{30,31,37,38 .}$

\section{4.2.1 Placental pathology in the Great Obstetrical Syndromes}

264 There is a range of placental vascular and thrombotic lesions that are being observed in placentas

265 of patients with pregnancy complications. Thrombotic events of placental vessels can cause an

266 impairment of placental perfusion, leading to fetal growth restriction (FGR), preeclampsia and

267 fetal death as well as in some extents to PTL and preterm PROM ${ }^{103,104}$. The frequency of the

268 specific vascular placental lesions varies among these obstetrical syndromes ${ }^{105}$.

269 Placental vascular lesions are divided into maternal or fetal vascular origin (figure 4-5) ${ }^{106,} 107$.

270 Lesions of the maternal vascular compartment include placental marginal and retro-placental

271 hemorrhages, lesions related to maternal under perfusion (acute atherosis and mural hypertrophy,

272 increased syncytial knots, villous agglutination, increased intervillous fibrin deposition, villous

273 infarcts $)^{106}$. Placental fetal vascular obstructive lesions are the result of stasis, hypercoagulability

274 and vascular damage within the fetal circulation of the placenta. Placental fetal vascular

275 abnormalities include: cord-related abnormalities (as torsion of cord, over-coiling, strictures and

276 tight knots ${ }^{108}$ ) and vascular lesions consistent with fetal thrombo-occlusive disease (thrombosis of

277 the chorionic plate and stem villous vessels, fibrotic, hypo-vascular and avascular villi ${ }^{106}$. In

278 addition, villitis of unknown etiology or chronic villitis, defined as lymphohistiocytic 
279 inflammation localized to the stroma of terminal villi but often extending to the small vessels of

280 upstream villi is also associated with obliterative fetal vasculopathy ${ }^{106}$ (Fig. 4-5).

281 Preeclampsia: The classical example for an association between obstetrical syndrome and 282 vascular placental lesions is preeclampsia. Women who develop preeclampsia have an increased 283 rate of abnormalities of the maternal side of the placental circulation and maternal 284 underperfusion ${ }^{109,110}$. The frequency of these lesions is inversely related to the gestational age in 285 which the hypertensive disorder was diagnosed. The earliest the development of 286 hypertension/preeclampsia the more severe are the vascular lesions ${ }^{111,112}$. Moreover, Kovo et al ${ }^{113}$

287 reported that the presence of fetal growth restriction in women with preeclampsia increases also 288 the frequency of fetal vascular lesions. Indeed, patients with early-onset preeclampsia 289 complicated by FGR had a higher rate of fetal-vascular supply lesions consistent with fetal 290 thrombo-occlusive disease than women with early-onset disease without $\mathrm{FGR}^{113}$.

291 An assessment of the pathologic changes in placental hemostatic system has been performed in 292 patients with preeclampsia. Teng et al ${ }^{114}$ studied TF and TFPI placental levels in pregnant patients 293 with preeclampsia, compared to normal pregnancies. They found increased TF placental 294 expression and a reduced expression of TFPI-1 and TFPI-2, with a significant correlation 295 between the levels of TF and TFPI-2 between maternal plasma and placenta.

296 Fetal growth restriction: Placentas from pregnancies complicated by FGR are smaller and have 297 significantly increased maternal and fetal vascular lesions compared to placentas from normal 298 pregnancies with appropriate for gestational age neonates (AGA) ${ }^{115}{ }^{116}$. Maternal vascular 299 lesions were detected in about $50 \%$ of placentas from pregnancies complicated with FGR at term, 300 compared to only $20 \%$ in normal pregnancies, while fetal vascular lesions were observed in $11 \%$ 301 of FGR pregnancies compared to only $4 \%$ in placentas from normal pregnancies ${ }^{113}$.

302 Placentas from normotensive pregnancies complicated by early-onset FGR $(<34$ weeks of 303 gestation) had a higher rate of low placental weight $(<10$ th percentile) and maternal 304 underperfusion, as compared to placentas of women who delivered AGA neonates $\leq 34$ weeks of 305 gestation ${ }^{115}$. Of interest, placentas from the late onset FGR group (after 34 weeks of gestation), in 306 addition to the high maternal vascular abnormalities, show also more fetal vascular abnormalities, 307 compared with AGA controls who delivered $>34$ weeks $^{117}$.

308 Fetal demise: Placental disease has been recognized as an important contributor to unexplained 309 fetal demise. Fetal vascular abnormalities ${ }^{105}$ are extensively involved in early and late fetal death 310 rather than maternal vascular lesions. In fetal death occurring prior to 34 weeks, an earlier and 
311 extended insult in the placental development occurs. On the other hand, late fetal demise is an

312 unpredicted event that is mostly characterized by non-thrombotic cord related lesions and less

313 placental vascular compromise ${ }^{107}$.

314 Preterm labor and preterm PROM: Placental studies in PTL demonstrated a combination of 315 inflammatory and vascular lesions. PTL is generally attributed to an inflammatory response 316 involving the bacterial induction of cytokine and prostanoid production ${ }^{118}$. Finding of histological 317 chorioamnionitis in PTL $^{119}$ has established infection and inflammation as a causative factor of 318 preterm birth, moreover, noninfectious trigger may also contribute to the development of preterm 319 labor and in some instances may be evident by placental sterile inflammatory response ${ }^{120}$. In 320 addition, isolated placental vascular lesions, mostly of maternal supply, were reported in $20 \%$ of 321 cases of PTL and an additional 20\% had combined inflammatory and vascular lesions. Moreover, 322 there are consistent reports describing increased rate of failure of transformation of the spiral 323 arteries in women with preterm labor without intrauterine infection/inflammation and in those 324 with preterm PROM than in women with normal pregnancies ${ }^{121}$. Such findings imply that an 325 inadequate uteroplacental blood flow due to abnormal placentation plays an important role in 326 pathogenesis of preterm parturition ${ }^{121,122}$.

327

328 Collectively, placental vascular lesions were reported in all the great obstetrical syndromes. The 329 severity of these lesions is associated with the timing of diagnosis of the disease. The more severe 330 the vascular injury, the more likely these complications will become clinically evident prior to 34 331 weeks of gestation. Of interest, vascular lesions often come along with evidence of acute 332 inflammation or lesions associated with chronic inflammatory processes, suggesting that 333 sometimes more than one mechanism is involved in development of a specific obstetrical 334 syndrome.

\subsection{Hemostatic changes in the amniotic fluid of women with obstetrical syndromes}

During normal pregnancy, there is an increase in the amniotic fluid TF concentration ${ }^{7,20-23}$. In

337 order to demonstrate the association of hemostatic changes and the development of obstetrical 338 complications, Erez et $\mathrm{al}^{54}$ studied the changes in the intra-amniotic concentration of TAT III 339 complexes, as well as TF concentration and activity, in cases of fetal demise and in normal 340 pregnancies.

341 Patients with a fetal demise had higher median amniotic fluid-TF concentration and activity than 342 those with normal pregnancies. Moreover, among patients with a FD there was a significant 343 correlation (Fig. 6) between the amniotic fluid-TF concentrations and activity $(\mathrm{r}=0.88, \mathrm{P}$ 
$344<0.0001)$. The median amniotic fluid- TAT III complexes concentration did not differ

345 significantly between the groups (normal pregnancy: median: $66.3 \mathrm{mg} / 1$, range 11.4-2265.4 vs.

346 FD: median: $59.3 \mathrm{mg} / \mathrm{l}$, range: $13.6-15,425.3$; P =0.7). In their study, the median amniotic fluid-

347 TF concentration in normal pregnant women was 10 fold higher than in maternal plasma.

348 The changes in amniotic fluid thrombin generation were reported also in women with preterm

349 parturition. Indeed, intra-amniotic infection and/or inflammation is associated with an increased

350 amniotic fluid TAT III complexes (Fig. 7). This is important since it represents an increased

351 thrombin generation in the amniotic cavity during infection and/or inflammation that may

352 contribute to uterine contractility and the development of preterm birth $^{123}$. Of interest, elevated

353 intra-amniotic TAT III concentrations were associated with a shorter amniocentesis to delivery

354 interval and an earlier gestational age at delivery only in patients with preterm labor without

355 intra-amniotic infection or inflammation ${ }^{123}$. This observation suggests that in a subset of patients

356 with preterm labor, activation of the coagulation system can generate preterm parturition and

357 delivery; while in those with intra-amniotic infection and/or inflammation the activation of the

358 coagulation and thrombin generation is a byproduct of the inflammatory process leading to 359 preterm birth.

360 This represents evidence of the activation and propagation of coagulation cascade, being

361 thrombin generation the witness of the former mechanisms and the inhibitor of the initiation 362 step $^{54}$.

\section{5. Conclusion}

364 The evidence presented herein suggests a role for increased thrombin generation and vascular 365 placental lesions in the pathogenesis of the great obstetrical syndromes. This process can be the 366 result of the contribution of procoagulant and vascular abnormalities as well as inflammatory and 367 infectious mechanisms, representing the starting point for pregnancy complications based on 368 vascular disease.

369 As presented, these changes affect the mother, the placenta, membranes and amniotic fluid.

370 Moreover, preliminary evidence suggest that some of the changes in the hemostatic system in the

371 mother and in the amniotic fluid predate the clinical presentation of the disease. Suggesting that

372 better understanding of the vascular and coagulation changes associated with the great obstetrical

373 syndromes may assist us in earlier detection and the development or introduction of therapeutic

374 modalities for these syndromes. 
References

377 1. Concise Medical Dictionary: Oxford University Press, 2010.

378 2. Romero R. Prenatal medicine: the child is the father of the man. 1996. J Matern Fetal $379 \quad$ Neonatal Med 2009;22:636-9.

380 3. Bellart J, Gilabert R, Miralles RM, Monasterio J, Cabero L. Endothelial cell markers and 381 fibrinopeptide A to D-dimer ratio as a measure of coagulation and fibrinolysis balance in normal pregnancy. Gynecol Obstet Invest 1998;46:17-21.

4. Walker MC, Garner PR, Keely EJ, Rock GA, Reis MD. Changes in activated protein C resistance during normal pregnancy. Am J Obstet Gynecol 1997;177:162-9.

5. Sørensen JD, Secher NJ, Jespersen J. Perturbed (procoagulant) endothelium and deviations within the fibrinolytic system during the third trimester of normal pregnancy. A possible link to placental function. Acta Obstet Gynecol Scand 1995;74:257-61.

6. Yuen PM, Yin JA, Lao TT. Fibrinopeptide A levels in maternal and newborn plasma. Eur J Obstet Gynecol Reprod Biol 1989;30:239-44.

7. de Boer K, ten Cate JW, Sturk A, Borm JJ, Treffers PE. Enhanced thrombin generation in normal and hypertensive pregnancy. Am J Obstet Gynecol 1989;160:95-100.

8. Chaiworapongsa T, Espinoza J, Yoshimatsu J, Kim YM, Bujold E, Edwin S, Yoon BH, Romero R. Activation of coagulation system in preterm labor and preterm premature rupture of membranes. J Matern Fetal Neonatal Med 2002;11:368-73.

9. Yoneyama Y, Suzuki S, Sawa R, Otsubo Y, Power GG, Araki T. Plasma adenosine levels increase in women with normal pregnancies. Am J Obstet Gynecol 2000;182:1200-3.

10. Sheu JR, Hsiao G, Luk HN, Chen YW, Chen TL, Lee LW, Lin CH, Chou DS. Mechanisms involved in the antiplatelet activity of midazolam in human platelets. Anesthesiology 2002;96:651-8.

11. Bremme KA. Haemostatic changes in pregnancy. Best Pract Res Clin Haematol 2003;16:153-68.

12. Eichinger S, Weltermann A, Philipp K, Hafner E, Kaider A, Kittl EM, Brenner B, Mannhalter C, Lechner K, Kyrle PA. Prospective evaluation of hemostatic system activation and thrombin potential in healthy pregnant women with and without factor $\mathrm{V}$ Leiden. Thromb Haemost. 1999;82:1232-6.

13. $\mathrm{Ku} \mathrm{DH}$, Arkel YS, Paidas MP, Lockwood CJ. Circulating levels of inflammatory cytokines (IL-1 beta and TNF-alpha), resistance to activated protein C, thrombin and fibrin generation in uncomplicated pregnancies. Thromb Haemost 2003;90:1074-9.

14. Lockwood CJ. Pregnancy-associated changes in the hemostatic system. Clin Obstet Gynecol 2006;49:836-43.

15. Erlich J, Parry GC, Fearns C, Muller M, Carmeliet P, Luther T, Mackman N. Tissue factor is required for uterine hemostasis and maintenance of the placental labyrinth during gestation. Proc Natl Acad Sci U S A 1999;96:8138-43.

16. Kuczyński J, Uszyński W, Zekanowska E, Soszka T, Uszyński M. Tissue factor (TF) and tissue factor pathway inhibitor (TFPI) in the placenta and myometrium. Eur J Obstet Gynecol Reprod Biol 2002;105:15-9.

17. Lockwood CJ, Krikun G, Schatz F. Decidual cell-expressed tissue factor maintains hemostasis in human endometrium. Ann N Y Acad Sci 2001;943:77-88.

18. Lockwood CJ, Krikun G, Schatz F. The decidua regulates hemostasis in human endometrium. Semin Reprod Endocrinol 1999;17:45-51.

19. Edstrom CS, Calhoun DA, Christensen RD. Expression of tissue factor pathway inhibitor in human fetal and placental tissues. Early Hum Dev 2000;59:77-84. 
423 20. Uszyński M, Zekanowska E, Uszyński W, Kuczyński J. Tissue factor (TF) and tissue factor pathway inhibitor (TFPI) in amniotic fluid and blood plasma: implications for the mechanism of amniotic fluid embolism. Eur J Obstet Gynecol Reprod Biol 2001;95:1636.

21. Lockwood CJ, Bach R, Guha A, Zhou XD, Miller WA, Nemerson Y. Amniotic fluid contains tissue factor, a potent initiator of coagulation. Am J Obstet Gynecol 1991;165:1335-41.

22. Omsjø IH, Oian P, Maltau JM, Osterud B. Thromboplastin activity in amniotic fluid. Gynecol Obstet Invest 1985;19:1-5.

23. Creter D. Amnioplastin: new reagent for coagulation tests. Lancet 1977;2:251.

24. Carmeliet P, Mackman N, Moons L, Luther T, Gressens P, Van Vlaenderen I, Demunck H, Kasper M, Breier G, Evrard P, Müller M, Risau W, Edgington T, Collen D. Role of tissue factor in embryonic blood vessel development. Nature 1996;383:73-5.

25. Holmes VA, Wallace JM. Haemostasis in normal pregnancy: a balancing act? Biochem Soc Trans 2005;33:428-32.

26. Reber G, Amiral J, de Moerloose P. Modified antithrombin III levels during normal pregnancy and relationship with prothrombin fragment F1 +2 and thrombin-antithrombin complexes. Thromb Res 1998;91:45-7.

27. Uszyński M. Generation of thrombin in blood plasma of non-pregnant and pregnant women studied through concentration of thrombin-antithrombin III complexes. Eur J Obstet Gynecol Reprod Biol 1997;75:127-31.

28. Reinthaller A, Mursch-Edlmayr G, Tatra G. Thrombin-antithrombin III complex levels in normal pregnancy with hypertensive disorders and after delivery. Br J Obstet Gynaecol 1990;97:506-10.

29. Andersson T, Lorentzen B, Hogdahl H, Clausen T, Mowinckel MC, Abildgaard U. Thrombin-inhibitor complexes in the blood during and after delivery. Thromb Res 1996;82:109-17.

30. Schjetlein R, Abdelnoor M, Haugen G, Husby H, Sandset PM, Wisløff F. Hemostatic variables as independent predictors for fetal growth retardation in preeclampsia. Acta Obstet Gynecol Scand 1999;78:191-7.

31. Chaiworapongsa T, Yoshimatsu J, Espinoza J, Kim YM, Berman S, Edwin S, Yoon BH, Romero R. Evidence of in vivo generation of thrombin in patients with small-forgestational-age fetuses and pre-eclampsia. J Matern Fetal Neonatal Med 2002;11:362-7.

32. Hayashi M, Numaguchi M, Ohkubo N, Yaoi Y. Blood macrophage colony-stimulating factor and thrombin-antithrombin III complex concentrations in pregnancy and preeclampsia. Am J Med Sci 1998;315:251-7.

33. Kobayashi T, Terao T. Preeclampsia as chronic disseminated intravascular coagulation. Study of two parameters: thrombin-antithrombin III complex and D-dimers. Gynecol Obstet Invest 1987;24:170-8.

34. Hayashi M1, Inoue T, Hoshimoto K, Negishi H, Ohkura T, Inaba N. Characterization of five marker levels of the hemostatic system and endothelial status in normotensive pregnancy and pre-eclampsia. Eur J Haematol 2002;69:297-302.

35. Hayashi M, Ohkura T. Elevated levels of serum macrophage colony-stimulating factor in normotensive pregnancies complicated by intrauterine fetal growth restriction. Exp Hematol 2002;30:388-93.

36. Ballard HS, Marcus AJ. Primary and secondary platelet aggregation in uraemia. Scand J Haematol 1972;9:198-203.

37. Erez O, Romer R, Vaisbuch E, Chaiworapongsa T, Kusanovic JP, Mazaki-Tovi S, Gotsch F, Gomez R, Maymon E, Pacora P, Edwin SS, Kim CJ, Than NG, Mittal P, Yeo L, Dong 
Z, Yoon BH, Hassan SS, Mazor M. Changes in amniotic fluid concentration of thrombinantithrombin III complexes in patients with preterm labor: evidence of an increased thrombin generation. J Matern Fetal Neonatal Med 2009;22:971-82.

38. Elovitz MA, Baron J, Phillippe M. The role of thrombin in preterm parturition. Am J Obstet Gynecol 2001;185:1059-63.

39. Rosen T, Kuczynski E, O'Neill LM, Funai EF, Lockwood CJ. Plasma levels of thrombinantithrombin complexes predict preterm premature rupture of the fetal membranes. $\mathrm{J}$ Matern Fetal Med 2001;10:297-300.

40. Kobayashi T, Tokunaga N, Sugimura M, Suzuki K, Kanayama N, Nishiguchi T, Terao T. Coagulation/fibrinolysis disorder in patients with severe preeclampsia. Semin Thromb Hemost 1999;25:451-4.

41. Kobayashi T, Sumimoto K, Tokunaga N, Sugimura M, Nishiguchi T, Kanayama N, Terao T. Coagulation index to distinguish severe preeclampsia from normal pregnancy. Semin Thromb Hemost 2002;28:495-500.

42. Lockwood CJ, Toti P, Arcuri F, Paidas M, Buchwalder L, Krikun G, Schatz F. Mechanisms of abruption-induced premature rupture of the fetal membranes: thrombinenhanced interleukin-8 expression in term decidua. Am J Pathol 2005;167:1443-9.

43. Gómez R, Romero R, Nien JK, Medina L, Carstens M, Kim YM, Chaiworapongsa T, Espinoza J, González R. Idiopathic vaginal bleeding during pregnancy as the only clinical manifestation of intrauterine infection. J Matern Fetal Neonatal Med 2005;18:31-7.

44. Gervasi MT, Chaiworapongsa T, Naccasha N, Pacora P, Berman S, Maymon E, Kim JC, Kim YM, Yoshimatsu J, Espinoza J, Romero R. Maternal intravascular inflammation in preterm premature rupture of membranes. J Matern Fetal Neonatal Med 2002;11:171-5.

45. Østerud B, Bjørklid E. Sources of tissue factor. Semin Thromb Hemost 2006;32:11-23.

46. Rosen T, Schatz F, Kuczynski E, Lam H, Koo AB, Lockwood CJ. Thrombin-enhanced matrix metalloproteinase-1 expression: a mechanism linking placental abruption with premature rupture of the membranes. J Matern Fetal Neonatal Med 2002;11:11-7.

47. Mackenzie AP, Schatz F, Krikun G, Funai EF, Kadner S, Lockwood CJ. Mechanisms of abruption-induced premature rupture of the fetal membranes: Thrombin enhanced decidual matrix metalloproteinase-3 (stromelysin-1) expression. Am J Obstet Gynecol 2004;191:1996-2001.

48. Elovitz MA, Ascher-Landsberg J, Saunders T, Phillippe M. The mechanisms underlying the stimulatory effects of thrombin on myometrial smooth muscle. Am J Obstet Gynecol 2000;183:674-81.

49. Elovitz MA1, Saunders T, Ascher-Landsberg J, Phillippe M. Effects of thrombin on myometrial contractions in vitro and in vivo. Am J Obstet Gynecol 2000;183:799-804.

50. Bilsel AS1, Onaran N, Moini H, Emerk K. Long-term effect of 17beta-estradiol and thrombin on tissue factor pathway inhibitor release from HUVEC. Thromb Res 2000;99:173-8.

51. VanWijk MJ, Boer K, Berckmans RJ, Meijers JC, van der Post JA, Sturk A, VanBavel E, Nieuwland R. Enhanced coagulation activation in preeclampsia: the role of APC resistance, microparticles and other plasma constituents. Thromb Haemost 2002;88:41520.

52. Erez O, Romero R, Vaisbuch E, Kusanovic JP, Mazaki-Tovi S, Chaiworapongsa T, Gotsch F, Fareed J, Hoppensteadt D, Than NG, Yoon BH, Edwin S, Dong Z, Espinoza J, Mazor M, Hassan SS. High tissue factor activity and low tissue factor pathway inhibitor concentrations in patients with preterm labor. J Matern Fetal Neonatal Med 2010;23:2333. 
520

521

522

523

524

525

526

527

528

529

530

531

532

533

534

535

536

537

538

539

540

541

542

543

544

545

546

547

548

549

550

551

552

553

554

555

556

557

558

559

560

561

562

563

564

565

566

53. Erez O, Romero R, Hoppensteadt D, Than NG, Fareed J, Mazaki-Tovi S, Espinoza J, Chaiworapongsa T, Kim SS, Yoon BH, Hassan SS, Gotsch F, Friel L, Vaisbuch E, Kusanovic JP. Tissue factor and its natural inhibitor in pre-eclampsia and SGA. J Matern Fetal Neonatal Med 2008;21:855-69.

54. Erez O, Gotsch F, Mazaki-Tovi S, Vaisbuch E, Kusanovic JP, Kim CJ, Chaiworapongsa T, Hoppensteadt D, Fareed J, Than NG, Nhan-Chang CL, Yeo L, Pacora P, Mazor M, Hassan SS, Mittal P, Romero R. Evidence of maternal platelet activation, excessive thrombin generation, and high amniotic fluid tissue factor immunoreactivity and functional activity in patients with fetal death. J Matern Fetal Neonatal Med 2009;22:672-87.

55. Beller FK, Ebert C. The coagulation and fibrinolytic enzyme system in pregnancy and in the puerperium. Eur J Obstet Gynecol Reprod Biol 1982;13:177-97.

56. Stirling Y, Woolf L, North WR, Seghatchian MJ, Meade TW. Haemostasis in normal pregnancy. Thromb Haemost 1984;52:176-82.

57. Brenner B. Haemostatic changes in pregnancy. Thromb Res 2004;114:409-14.

58. Romero R, Gonçalves LF, Kusanovic JP, Devesa R, Espinoza J. Mechanisms of preterm labor and preterm premature rupture of the membranes. In: Kurjak A, Chervenak F, eds. Textbook of Perinatal Medicine 2nd Edition, 2006.

59. Lockwood CJ, Krikun G, Rahman M, Caze R, Buchwalder L, Schatz F. The role of decidualization in regulating endometrial hemostasis during the menstrual cycle, gestation, and in pathological states. Semin Thromb Hemost 2007;33:111-7.

60. Broze GJ Jr, Warren LA, Novotny WF, Higuchi DA, Girard JJ, Miletich JP. The lipoprotein-associated coagulation inhibitor that inhibits the factor VII-tissue factor complex also inhibits factor Xa: insight into its possible mechanism of action. Blood 1988;71:335-43.

61. Laskowski M, Kato I. Protein inhibitors of proteinases. Annu Rev Biochem 1980;49:593626.

62. Broze GJ, Girard TJ, Novotny WF. Regulation of coagulation by a multivalent Kunitztype inhibitor. Biochemistry 1990;29:7539-46.

63. Sarig G, Blumenfeld Z, Leiba R, Lanir N, Brenner B. Modulation of systemic hemostatic parameters by enoxaparin during gestation in women with thrombophilia and pregnancy loss. Thromb Haemost 2005;94:980-5.

64. Tay SP, Cheong SK, Boo NY. Circulating tissue factor, tissue factor pathway inhibitor and D-dimer in umbilical cord blood of normal term neonates and adult plasma. Blood Coagul Fibrinolysis 2003;14:125-9.

65. Hubé F, Reverdiau P, Iochmann S, Trassard S, Thibault G, Gruel Y. Demonstration of a tissue factor pathway inhibitor 2 messenger RNA synthesis by pure villous cytotrophoblast cells isolated from term human placentas. Biol Reprod 2003;68:1888-94.

66. Iino M, Foster DC, Kisiel W. Quantification and characterization of human endothelial cell-derived tissue factor pathway inhibitor-2. Arterioscler Thromb Vasc Biol 1998;18:406.

67. Sprecher CA, Kisiel W, Mathewes S, Foster DC. Molecular cloning, expression, and partial characterization of a second human tissue-factor-pathway inhibitor. Proc Natl Acad Sci U S A 1994;91:3353-7.

68. Udagawa K, Miyagi Y, Hirahara F, Miyagi E, Nagashima Y, Minaguchi H, Misugi K, Yasumitsu H, Miyazaki K. Specific expression of PP5/TFPI2 mRNA by syncytiotrophoblasts in human placenta as revealed by in situ hybridization. Placenta 1998;19:217-23. 
567 69. Kamei S, Kazama Y, Kuijper JL, Foster DC, Kisiel W. Genomic structure and promoter

70. Kisiel W, Sprecher CA, Foster DC. Evidence that a second human tissue factor pathway 2001;1517:430-5.

inhibitor (TFPI-2) and human placental protein 5 are equivalent. Blood 1994;84:4384-5.

71. Bützow R, Virtanen I, Seppälä M, Närvänen O, Stenman UH, Ristimäki A, Bohn H. Monoclonal antibodies reacting with placental protein 5: use in radioimmunoassay, Western blot analysis, and immunohistochemistry. J Lab Clin Med 1988;111:249-56.

72. Chand HS, Foster DC, Kisiel W. Structure, function and biology of tissue factor pathway inhibitor-2. Thromb Haemost 2005;94:1122-30.

73. Seppälä M, Wahlström T, Bohn H. Circulating levels and tissue localization of placental protein five (PP5) in pregnancy and trophoblastic disease: absence of PP5 expression in the malignant trophoblast. Int J Cancer 1979;24:6-10.

74. Obiewke BC, Chard T. Placental protein 5: circulating levels in twin pregnancy and some observations on the analysis of biochemical data from multiple pregnancy. Eur J Obstet Gynecol Reprod Biol 1981;12:135-41.

75. Shimura M, Wada H, Wakita Y, Nakase T, Hiyoyama K, Nagaya S, Mori Y, Shiku H. Plasma tissue factor and tissue factor pathway inhibitor levels in patients with disseminated intravascular coagulation. Am J Hematol 1997;55:169-74.

76. Abdel Gader AM, Al-Mishari AA, Awadalla SA, Buyuomi NM, Khashoggi T, Al-Hakeem M. Total and free tissue factor pathway inhibitor in pregnancy hypertension. Int J Gynaecol Obstet 2006;95:248-53.

77. Erez O, Espinoza J, Chaiworapongsa T, Gotsch F, Kusanovic JP, Than NG, Mazaki-Tovi S, Vaisbuch E, Papp Z, Yoon BH, Han YM, Hoppensteadt D, Fareed J, Hassan SS, Romero R. A link between a hemostatic disorder and preterm PROM: a role for tissue factor and tissue factor pathway inhibitor. J Matern Fetal Neonatal Med 2008;21:732-44.

78. Xiong Y, Zhou Q, Jiang F, Zhou S, Lou Y, Guo Q, Liang W, Kong D, Ma D, Li X. Changes of plasma and placental tissue factor pathway inhibitor-2 in women with preeclampsia and normal pregnancy. Thromb Res 2010;125:e317-22.

79. Aharon A, Lanir N, Drugan A, Brenner B. Placental TFPI is decreased in gestational vascular complications and can be restored by maternal enoxaparin treatment. $\mathrm{J}$ Thromb Haemost 2005;3:2355-7.

80. Castoldi E, Hackeng TM. Regulation of coagulation by protein S. Curr Opin Hematol 2008;15:529-36.

81. Hackeng TM, Seré KM, Tans G, Rosing J. Protein S stimulates inhibition of the tissue factor pathway by tissue factor pathway inhibitor. Proc Natl Acad Sci U S A 2006;103:3106-11.

82. Ndonwi M, Broze G. Protein S enhances the tissue factor pathway inhibitor inhibition of factor Xa but not its inhibition of factor VIIa-tissue factor. $\mathrm{J}$ Thromb Haemost 2008;6:1044-6.

83. Faught W, Garner P, Jones G, Ivey B. Changes in protein C and protein S levels in normal pregnancy. Am J Obstet Gynecol 1995;172:147-50.

84. Dahlbäck B, Carlsson M, Svensson PJ. Familial thrombophilia due to a previously unrecognized mechanism characterized by poor anticoagulant response to activated protein C: prediction of a cofactor to activated protein C. Proc Natl Acad Sci U S A 1993;90:1004-8.

85. Rodger MA, Paidas M, McLintock C, Middeldorp S, Kahn S, Martinelli I, Hague W, Rosene Montella K, Greer I. Inherited thrombophilia and pregnancy complications revisited. Obstet Gynecol 2008;112:320-4. 
616 86. Yalinkaya A, Erdemoglu M, Akdeniz N, Kale A, Kale E. The relationship between

617 thrombophilic mutations and preeclampsia: a prospective case-control study. Ann Saudi

618 Med 2006;26:105-9.

619 87. Preston FE, Rosendaal FR, Walker ID, Briët E, Berntorp E, Conard J, Fontcuberta J,

620 Makris M, Mariani G, Noteboom W, Pabinger I, Legnani C, Scharrer I, Schulman S, van

621 der Meer FJ. Increased fetal loss in women with heritable thrombophilia. Lancet

622 1996;348:913-6.

623 88. Kupferminc MJ, Many A, Bar-Am A, Lessing JB, Ascher-Landsberg J. Mid-trimester

624 severe intrauterine growth restriction is associated with a high prevalence of

625 thrombophilia. BJOG 2002;109:1373-6.

626 89. Han X, Fiehler R, Broze GJ. Isolation of a protein Z-dependent plasma protease inhibitor.

$627 \quad$ Proc Natl Acad Sci U S A 1998;95:9250-5.

628 90. Han X, Huang ZF, Fiehler R, Broze GJ Jr. The protein Z-dependent protease inhibitor is a 629 serpin. Biochemistry 1999;38:11073-8.

630 91. Han X, Fiehler R, Broze GJ. Characterization of the protein Z-dependent protease 631 inhibitor. Blood 2000;96:3049-55.

632 92. Yin ZF, Huang ZF, Cui J, Fiehler R, Lasky N, Ginsburg D, Broze GJ Jr. Prothrombotic

633

634 phenotype of protein Z deficiency. Proc Natl Acad Sci U S A 2000;97:6734-8.

635

636

637

638

639

640

641

642

643

644

645

646

647

648

649

650

651

652

653

654

655

656

657

658

659

660

661

662

663

93. Taylor FB, Chang AC, Peer G, Li A, Ezban M, Hedner U. Active site inhibited factor VIIa (DEGR VIIa) attenuates the coagulant and interleukin-6 and -8 , but not tumor necrosis factor, responses of the baboon to LD100 Escherichia coli. Blood 1998;91:1609-15.

94. Kusanovic JP, Espinoza J, Romero R, Hoppensteadt D, Nien JK, Kim CJ, Erez O, Soto E, Fareed J, Edwin S, Chaiwerapongsa T, Than NG, Yoon BH, Gomez R, Papp Z, Hassan SS. Plasma protein $\mathrm{Z}$ concentrations in pregnant women with idiopathic intrauterine bleeding and in women with spontaneous preterm labor. J Matern Fetal Neonatal Med 2007;20:453-63.

95. Bretelle F, Arnoux D, Shojai R, D'Ercole C, Sampol J, Dignat F, Camoin-Jau L. Protein Z in patients with pregnancy complications. Am J Obstet Gynecol 2005;193:1698-702.

96. Nien JK, Romero R, Hoppensteadt D, Erez O, Espinoza J, Soto E, Kusanovic JP, Gotsch F, Kim CJ, Mittal P, Fareed J, Santolaya J, Chaiworapongsa T, Edwin S, Pineles B, Hassan S. Pyelonephritis during pregnancy: a cause for an acquired deficiency of protein Z. J Matern Fetal Neonatal Med 2008;21:629-37.

97. Sood R, Kalloway S, Mast AE, Hillard CJ, Weiler H. Fetomaternal cross talk in the placental vascular bed: control of coagulation by trophoblast cells. Blood 2006;107:317380 .

98. Sood R, Sholl L, Isermann B, Zogg M, Coughlin SR, Weiler H. Maternal Par4 and platelets contribute to defective placenta formation in mouse embryos lacking thrombomodulin. Blood 2008;112:585-91.

99. Lanir N, Aharon A, Brenner B. Procoagulant and anticoagulant mechanisms in human placenta. Semin Thromb Hemost 2003;29:175-84.

100. Isermann B, Sood R, Pawlinski R, Zogg M, Kalloway S, Degen JL, Mackman N, Weiler $\mathrm{H}$. The thrombomodulin-protein $\mathrm{C}$ system is essential for the maintenance of pregnancy. Nat Med 2003;9:331-7.

101. Aharon A, Brenner B, Katz T, Miyagi Y, Lanir N. Tissue factor and tissue factor pathway inhibitor levels in trophoblast cells: implications for placental hemostasis. Thromb Haemost 2004;92:776-86.

102. Butenas S, Orfeo T, Brummel-Ziedins KE, Mann KG. Tissue factor in thrombosis and hemorrhage. Surgery 2007;142:S2-14. 
664 103. Midderdorp S. Thrombophilia and pregnancy complications: cause or association? J

665

666

667

668

669

670

671

672

673

674

675

676

677

678

679

680

681

682

683

684

685

686

687

688

689

690

691

692

693

694

695

696

697

698

699

700

701

702

703

704

705

706

707

708

709

710

104. Martinelli I, Legnani C, Bucciarelli P, Grandone E, De Stefano V, Mannucci PM. Risk of pregnancy-related venous thrombosis in carriers of severe inherited thrombophilia. Thromb Haemost 2001;86:800-3.

105. Kovo M, Schreiber L, Bar J. Placental vascular pathology as a mechanism of disease in pregnancy complications. Thromb Res 2013;131 Suppl 1:S18-21.

106. Redline RW, Heller D, Keating S, Kingdom J. Placental diagnostic criteria and clinical correlation--a workshop report. Placenta 2005;26 Suppl A:S114-7.

107. Bar J, Schreiber L, Ben-Haroush A, Ahmed H, Golan A, Kovo M. The placental vascular component in early and late intrauterine fetal death. Thromb Res 2012;130:901-5.

108. Cromi A, Ghezzi F, Dürig P, Di Naro E, Raio L. Sonographic umbilical cord morphometry and coiling patterns in twin-twin transfusion syndrome. Prenat Diagn 2005;25:851-5.

109. Salafia CM, Pezzullo JC, Ghidini A, Lopèz-Zeno JA, Whittington SS. Clinical correlations of patterns of placental pathology in preterm pre-eclampsia. Placenta 1998;19:67-72.

110. Roberts DJ, Post MD. The placenta in pre-eclampsia and intrauterine growth restriction. J Clin Pathol 2008;61:1254-60.

111. Mayhew TM, Ohadike C, Baker PN, Crocker IP, Mitchell C, Ong SS. Stereological investigation of placental morphology in pregnancies complicated by pre-eclampsia with and without intrauterine growth restriction. Placenta 2003;24:219-26.

112. Ogge G, Chaiworapongsa T, Romero R, Hussein Y, Kusanovic JP, Yeo L, Kim CJ, Hassan SS. Placental lesions associated with maternal underperfusion are more frequent in earlyonset than in late-onset preeclampsia. J Perinat Med 2011;39:641-52.

113. Kovo M, Schreiber L, Ben-Haroush A, Wand S, Golan A, Bar J. Placental vascular lesion differences in pregnancy-induced hypertension and normotensive fetal growth restriction. Am J Obstet Gynecol 2010;202:561.e1-5.

114. Teng Y, Jiang R, Lin Q, Ding C, Ye Z. The relationship between plasma and placental tissue factor, and tissue factor pathway inhibitors in severe pre-eclampsia patients. Thromb Res 2010;126:e41-5.

115. Rerdline RW. Placental pathology: a systematic approach with clinical correlations. Placenta 2008;29 Suppl A:S86-91.

116. Salafia CM, Minior VK, Pezzullo JC, Popek EJ, Rosenkrantz TS, Vintzileos AM. Intrauterine growth restriction in infants of less than thirty-two weeks' gestation: associated placental pathologic features. Am J Obstet Gynecol 1995;173:1049-57.

117. Kovo M, Schreiber L, Ben-Haroush A, Gold E, Golan A, Bar J. The placental component in early-onset and late-onset preeclampsia in relation to fetal growth restriction. Prenat Diagn 2012;32:632-7.

118. Romero R, Espinoza J, Kusanovic JP, Gotsch F, Hassan S, Erez O, Chaiworapongsa T, Mazor M. The preterm parturition syndrome. BJOG 2006;113 Suppl 3:17-42.

119. Arias F, Rodriquez L, Rayne SC, Kraus FT. Maternal placental vasculopathy and infection: two distinct subgroups among patients with preterm labor and preterm ruptured membranes. Am J Obstet Gynecol 1993;168:585-91.

120. Nath CA, Ananth CV, Smulian JC, Shen-Schwarz S, Kaminsky L; New Jersey-Placental Abruption Study Investigators. Histologic evidence of inflammation and risk of placental abruption. Am J Obstet Gynecol 2007;197:319.e1-6. 
711 121. Kim YM, Chaiworapongsa T, Gomez R, Bujold E, Yoon BH, Rotmensch S, Thaler HT,

712

713

714

715

716

717 Romero R. Failure of physiologic transformation of the spiral arteries in the placental bed in preterm premature rupture of membranes. Am J Obstet Gynecol 2002;187:1137-42.

122. Salafia CM, Vogel CA, Vintzileos AM, Bantham KF, Pezzullo J, Silberman L. Placental pathologic findings in preterm birth. Am J Obstet Gynecol 1991;165:934-8.

123. Stephenson CD, Lockwood CJ, Ma Y, Guller S. Thrombin-dependent regulation of matrix metalloproteinase (MMP)-9 levels in human fetal membranes. J Matern Fetal Neonatal Med 2005;18:17-22. 
719 Figure 1. Thrombin-antithrombin III (TAT) levels in control patients, patients with preterm labor 720 who delivered between 21 and 7 days, and patients with preterm labor who delivered within 7 721 days. Open diamonds, Mean levels; black error bars, SD. *P <.05, Student-Newman-Keuls 722 method (from Elovitz MA, Baron J, Phillippe M. The role of thrombin in preterm parturition. Am 723 J Obstet Gynecol 2001 Nov;185(5):1059-1063. With permission).

724 Figure 2. (a) Comparison of median maternal plasma TF concentration between patients with 725 normal pregnancy $(\mathrm{n}=79)$, pre-eclampsia $(\mathrm{n}=133)$, and women who delivered an SGAneonate 726 ( $\mathrm{n}=61)$. (b) Comparison of median maternal plasma TFPI concentration between patients with 727 normal pregnancy $(\mathrm{n}=86)$, pre-eclampsia $(\mathrm{n}=133)$, and women who delivered an SGA neonate 728 ( $\mathrm{n}=61)$. (c) Comparison of maternal plasma TFPI/TF ratio between women with normal 729 pregnancy $(\mathrm{n}=79)$, pre-eclampsia $(\mathrm{n}=133)$, and women who delivered an SGA neonate $(\mathrm{n}=61)$.

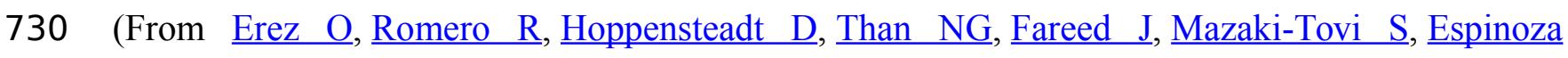

731 J, Chaiworapongsa T, Kim SS, Yoon BH,$\underline{\text { Hassan SS }}$, Gotsch F, Friel L, Vaisbuch E, Kusanovic 732 JP. Tissue factor and its natural inhibitor in pre-eclampsia and SGA. J Matern Fetal Neonatal 733 Med. 2008 Dec;21(12):855-69. With permission).

734 Figure 3. Factor $\mathrm{X}$ activation and protein $\mathrm{Z} /$ protein $\mathrm{Z}$-dependent protease inhibitor (ZPI) 735 inhibition of activated factor X. (a) Then formation of the complex of tissue factor (TF) and 736 factor VIIa (FVIIa) at the site of injury and activation of extrinsic coagulation cascade. (b) 737 Activation of circulating factor $\mathrm{X}$ by the TFpFVIIa complex in the presence of exposed 738 phospholipids and $\mathrm{Ca} 2 \mathrm{p}$. (c) Inhibition of factor Xa (FXa) by the protein Z/ZPI complex by 739 binding to its active site. Modified from Broze JG, Lancet 2001;357:900-901.

740 Figure 4. Histologic features of maternal vessel and implantation site reaction patterns: a. Acute 741 atherosis of maternal arterioles in the placental membranes: a cluster of decidual arterioles shows 742 varying stages of fibrinoid necrosis. The vessel at the upper right shows full histologic expression

743 with dark homogenous fibrinoid replacement of the vessel wall accompanied by occasional 744 foamy macrophages ([original magnification is indicated for all panels] X 20). b. Mural 
745 hypertrophy of decidual arterioles in the placental membranes: a cluster of arterioles shows

746 medial hypertrophy with the vessel wall occupying greater than one third of total vessel diameter

747 (X 10). c. Muscularized basal plate arteries with accompanying implantation site abnormalities:

748 maternal spiral arteries in the basal plate lack normal trophoblast remodeling and retain their pre-

749 pregnancy muscular media. Clusters of immature intermediate trophoblast and increased

750 placental giant cells are seen above and below the muscular arteries, respectively (X 10). d. Acute

751 atherosis of muscularized basal plate arteries with accompanying implantation site abnormalities:

752 three cross sections of a basal plate artery are seen. The two on the left show persistence of the

753 muscular media while the one on the right has undergone fibrinoid necrosis of the media with

754 foamy macrophages (acute atherosis). Clusters of immature intermediate trophoblast are also

755 seen overlying the arteries (X 4). e. Immature intermediate trophoblast: clusters of abnormally

756 small intermediate trophoblast with focal vacuolation are surrounded by an excessive amount of

757 basal plate fibrin. Increased placental site giant cells are also seen at the lower margin (X 10). $f$.

758 Increased placental site giant cells: numerous multinucleate placental site giant cells, not usually

759 seen in the delivered placenta, are scattered in loose decidual tissue which is devoid of normal

760 intermediate trophoblast and fibrinoid (X 10).

761 From: Redline RW, et al. Maternal vascular underperfusion: nosology and reproducibility of

762 placental reaction patterns. Pediatr Dev Pathol. 2004;7(3):237-49. With permission.

763 Figure 5. Histologic features of villous and intervillous lesions; a. Increased syncytial knots:

764 aggregates of syncytiotrophoblast nuclei cluster at one or more poles of distal villi in the vicinity

765 of larger stem villi (arrowhead) at the periphery of the lobule ([original magnification is indicated

766 for all panels] X 10). b. Villous agglutination: clusters of degenerating distal villi are adherent to

767 one another and focally enmeshed in fibrin (X 4). c. Distal villous hypoplasia: a long, thin, non-

768 branching stem villus is surrounded by a markedly reduced number of small hypoplastic distal

769 villi (X 10). d. Increased intervillous fibrin: stem villi are surrounded by a mantle of fibrin-type

770 fibrinoid that does not extend to distal villi at the center of the lobule (X 2). e. Nodular

771 intervillous (and intravillous) fibrin: small aggregates of intervillous fibrin adhere to, and are

772 focally reepithelialized by, distal villous trophoblast (X 20). f. Increased intervillous fibrin with 
773 intermediate trophoblast (X-cells): stem and distal villi are enmeshed in a matrix of fibrin and

774 fibrinoid containing prominent intermediate trophoblast (arrowhead) (X 10).

775 From: Redline RW, et al. Maternal vascular underperfusion: nosology and reproducibility of

776 placental reaction patterns. Pediatr Dev Pathol. 2004;7(3):237-49. With permission.

777 Figure 6. Amniotic fluid tissue factor concentration among women with normal pregnancies

778 (median $3710.4 \mathrm{pg} / \mathrm{ml}$, range 2198.8-6268) and patients with a fetal demise (median 8535.4

$779 \mathrm{pg} / \mathrm{ml}$, range 2208.2-125,990.0); (b) Amniotic fluid tissue factor activity among women with

780 normal pregnancies (median $28.4 \mathrm{pM}$, range 10.2-84.9) and patients with a fetal demise (median

78181.6 pM, range 7.2-1603.4). From Erez O, Gotsch F, MAZAKi-Tovi S, et al. Evidence of 782 maternal platelet activation, excessive thrombin generation, and high amniotic fluid tissue factor

783 immunoreactivity and functional activity in patients with fetal death. J Matern Fetal Neonatal

784 Med 2009;22:672-87, with permission.

785 Figure 7. Maternal plasma TAT III concentration in women with preterm labor (PTL) and those 786 with a Normal pregnancy (From Chaiworapongsa T, Espinoza J, Yoshimatsu J, Kim YM, Bujold

787 E, Edwin S, et al. Activation of coagulation system in preterm labor and preterm premature 788 rupture of membranes. J Matern Fetal Neonatal Med 2002 11(6):368-373, with permission). 


\section{Table 1 (on next page)}

Table 1

Table 1. Concentration and activity in maternal plasma of coagulating and anticoagulating factors and their relation with thrombin generation in the great obstetrical syndromes. 
1 Table 1. Concentration and activity in maternal plasma of coagulating and anticoagulating factors and

2 their relation with thrombin generation in the great obstetrical syndromes.

\begin{tabular}{|c|c|c|c|c|c|c|}
\hline & $\begin{array}{l}\text { TF concentration } \\
\text { and/or activity }\end{array}$ & $\begin{array}{c}\text { TFPI } \\
\text { concentration } \\
\text { and/or activity }\end{array}$ & $\begin{array}{c}\text { TAT III } \\
\text { complexes } \\
\text { concentration }\end{array}$ & $\begin{array}{c}\text { Protein } \mathrm{Z} \\
\text { concentration }\end{array}$ & $\begin{array}{l}\text { Thrombin } \\
\text { generation }\end{array}$ & References \\
\hline $\begin{array}{l}\text { Premature rupture } \\
\text { of membranes }\end{array}$ & $\begin{array}{ll}\text { Activity } & \uparrow \\
\text { Concentration } & \uparrow\end{array}$ & Concentration $\downarrow$ & Concentration $\uparrow$ & Concentration $\downarrow$ & $\uparrow$ & $1-5$ \\
\hline Preterm labor & $\begin{array}{ll}\text { Activity } & \uparrow \\
\text { Concentration } & =\end{array}$ & $\begin{array}{ll}\text { Activity } & = \\
\text { Concentration } & \downarrow\end{array}$ & Concentration $\uparrow$ & Concentration $\downarrow$ & $\uparrow$ & $1-5$ \\
\hline Fetal demise & $\begin{array}{ll}\text { Activity } & = \\
\text { Concentration } & =\end{array}$ & $\begin{array}{ll}\text { Activity } & = \\
\text { Concentration } & \downarrow\end{array}$ & Concentration $\uparrow$ & Concentration $\downarrow$ & $\uparrow$ & $1-5$ \\
\hline Preeclampsia & $\begin{array}{ll}\text { Activity } & \uparrow \\
\text { Concentration } & \uparrow\end{array}$ & Concentration $\uparrow$ & Concentration $\uparrow$ & Concentration $\downarrow$ & $\uparrow$ & $1-5$ \\
\hline $\begin{array}{l}\text { Intrauterine } \\
\text { growth retardation }\end{array}$ & Concentration $\downarrow$ & Concentration $=$ & Concentration $\uparrow$ & Concentration $\downarrow$ & $\uparrow$ & $1-5$ \\
\hline
\end{tabular}

3 1. Erez O, Romero R, Vaisbuch E, Kusanovic JP, Mazaki-Tovi S, Chaiworapongsa T, Gotsch F, Fareed J, Hoppensteadt D, Than NG, Yoon BH,

4 Edwin S, Dong Z, Espinoza J, Mazor M, Hassan SS. High tissue factor activity and low tissue factor pathway inhibitor concentrations in patients

5 with preterm labor. J Matern Fetal Neonatal Med. 2010 Jan;23(1):23-33

6 2. Erez O, Gotsch F, Mazaki-Tovi S, Vaisbuch E, Kusanovic JP, Kim CJ, Chaiworapongsa T, Hoppensteadt D, Fareed J, Than NG, Nhan-Chang

7 CL, Yeo L, Pacora P, Mazor M, Hassan SS, Mittal P, Romero R. Evidence of maternal platelet activation, excessive thrombin generation, and high

8 amniotic fluid tissue factor immunoreactivity and functional activity in patients with fetal death. J Matern Fetal Neonatal Med. 2009

9 Aug;22(8):672-87

3. Kusanovic JP, Espinoza J, Romero R, Hoppensteadt D, Nien JK, Kim CJ, et al. Plasma protein Z concentrations in pregnant women with

4. Gris JC, Quere I, Dechaud H, Mercier E, Pincon C, Hoffet M, Vasse M, Mares P. High frequency of protein Z deficiency in patients with unexplained early fetal loss. Blood 2002;99:2606-2608 
Figure 1 (on next page)

Figure 1

Thrombin-antithrombin III (TAT) levels in control patients, patients with preterm labor who delivered between 21 and 7 days, and patients with preterm labor who delivered within 7 days. Open diamonds, Mean levels; black error bars, SD. *P <.05, Student-Newman-Keuls method (from Elovitz MA, Baron J, Phillippe M. The role of thrombin in preterm parturition. Am J Obstet Gynecol 2001 Nov;185(5):1059-1063. With permission). 


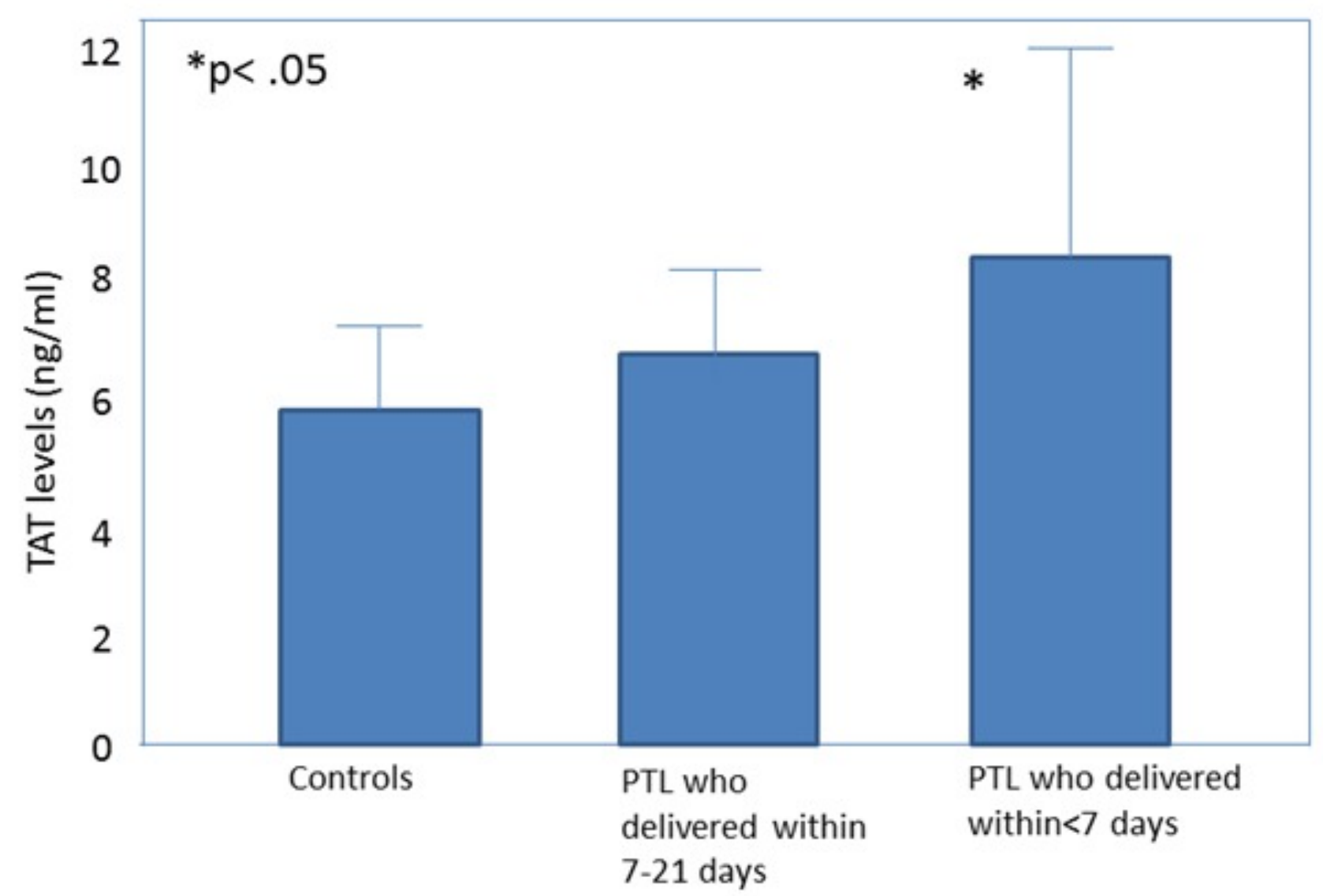




\section{Figure 2 (on next page)}

\section{Figure 2}

Figure 2. (a) Comparison of median maternal plasma TF concentration between patients with normal pregnancy $(n=79)$, pre-eclampsia $(n=133)$, and women who delivered an SGAneonate $(n=61)$. (b) Comparison of median maternal plasma TFPI concentration between patients with normal pregnancy $(n=86)$, pre-eclampsia $(n=133)$, and women who delivered an SGA neonate $(n=61)$. (c) Comparison of maternal plasma TFPI/TF ratio between women with normal pregnancy $(n=79)$, pre-eclampsia $(n=133)$, and women who delivered an SGA neonate $(n=61)$. (From Erez 0 , Romero R , Hoppensteadt D , Than NG , Fareed J , MazakiTovi S , Espinoza J , Chaiworapongsa T , Kim SS , Yoon BH , Hassan SS , Gotsch F , Friel L , Vaisbuch E , Kusanovic JP. Tissue factorand itsnaturalinhibitor in pre-eclampsia and SGA. J Matern Fetal Neonatal Med. 2008 Dec;21(12):855-69. With permission). 


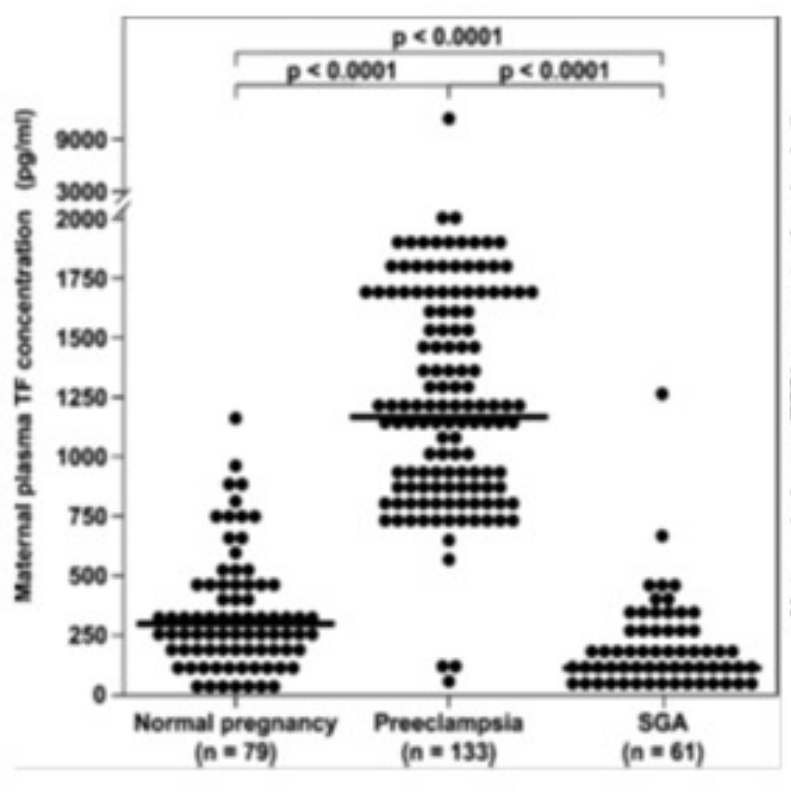

(a)

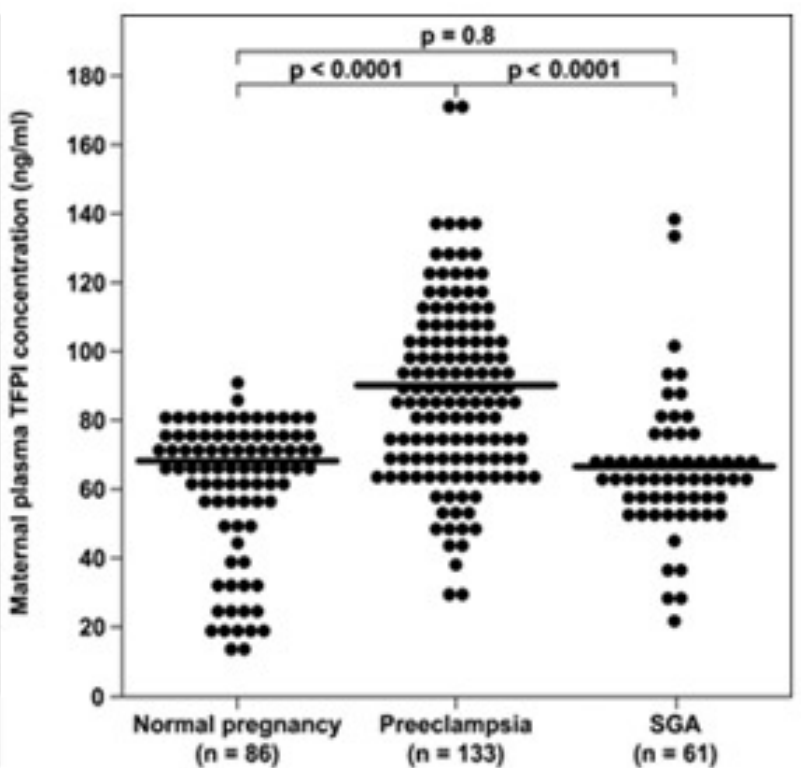

(b)

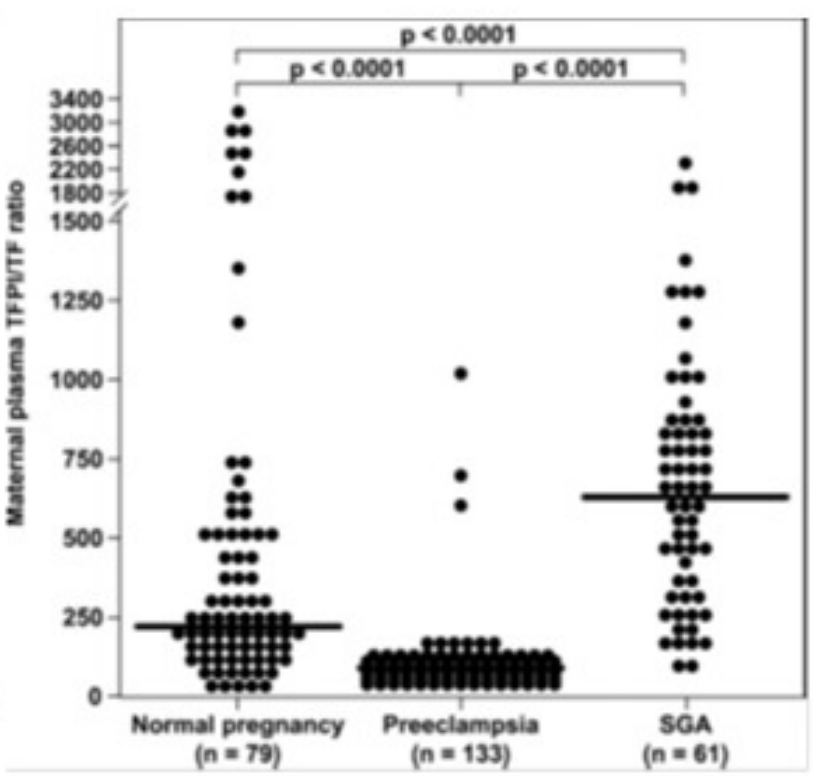

(c) 
Figure $\mathbf{3}$ (on next page)

Figure 3

Factor $\mathrm{X}$ activation and protein Z/protein Z-dependent protease inhibitor (ZPI) inhibition of activated factor X. (a) Then formation of the complex of tissue factor (TF) and factor VIla (FVIla) at the site of injury and activation of extrinsic coagulation cascade. (b) Activation of circulating factor $\mathrm{X}$ by the TFPFVIla complex in the presence of exposed phospholipids and Ca2p. (c) Inhibition of factor Xa (FXa) by the protein Z/ZPI complex by binding to its active site. Modified from Broze JG, Lancet 2001;357:900-901. 


\section{Figure 4 (on next page)}

\section{Figure 4}

Histologic features of maternal vessel and implantation site reaction patterns: a. Acute atherosis of maternal arterioles in the placental membranes: a cluster of decidual arterioles shows varying stages of fibrinoid necrosis. The vessel at the upper right shows full histologic expression with dark homogenous fibrinoid replacement of the vessel wall accompanied by occasional foamy macrophages ([original magnification is indicated for all panels] X .(20 b. Mural hypertrophy of decidual arterioles in the placental membranes: a cluster of arterioles shows medial hypertrophy with the vessel wall occupying greater than one third of total vessel diameter (X 10). c. Muscularized basal plate arteries with accompanying implantation site abnormalities: maternal spiral arteries in the basal plate lack normal trophoblast remodeling and retain their pre-pregnancy muscular media. Clusters of immature intermediate trophoblast and increased placental giant cells are seen above and below the muscular arteries, respectively (X 10). d. Acute atherosis of muscularized basal plate arteries with accompanying implantation site abnormalities: three cross sections of a basal plate artery are seen. The two on the left show persistence of the muscular media while the one on the right has undergone fibrinoid necrosis of the media with foamy macrophages (acute atherosis). Clusters of immature intermediate trophoblast are also seen overlying the arteries (X 4). e. Immature intermediate trophoblast: clusters of abnormally small intermediate trophoblast with focal vacuolation are surrounded by an excessive amount of basal plate fibrin. Increased placental site giant cells are also seen at the lower margin (X . (10 f. Increased placental site giant cells: numerous multinucleate placental site giant cells, not usually seen in the delivered placenta, are scattered in loose decidual tissue which is devoid of normal intermediate trophoblast and fibrinoid (X .(10 From: Redline RW, et al. Maternal vascular underperfusion: nosology and reproducibility of placental reaction patterns. Pediatr Dev Pathol. 2004;7(3):237-49. With permission. 


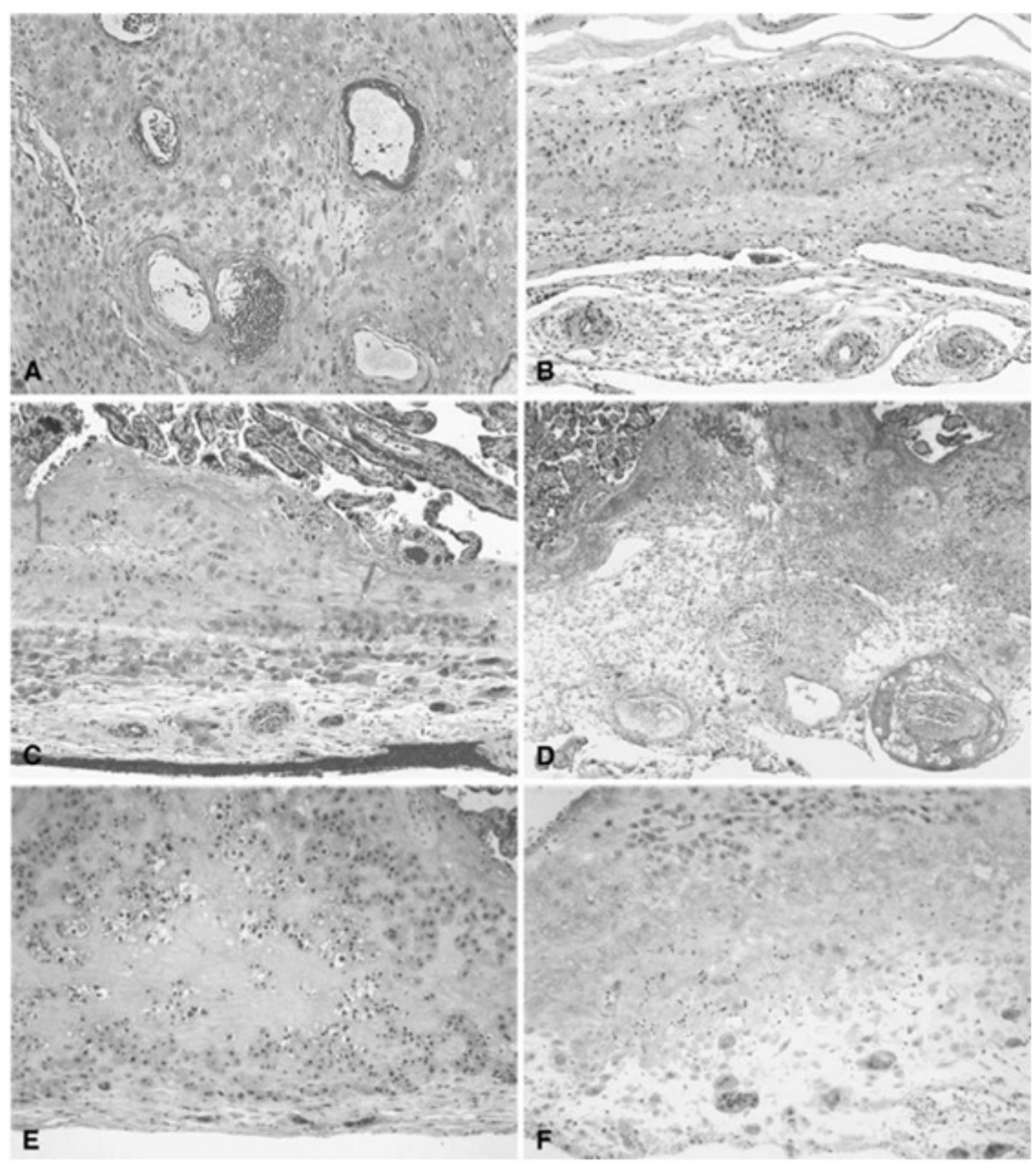




\section{Figure 5 (on next page)}

\section{Figure 5}

Histologic features of villous and intervillous lesions; a. Increased syncytial knots: aggregates of syncytiotrophoblast nuclei cluster at one or more poles of distal villi in the vicinity of larger stem villi (arrowhead) at the periphery of the lobule ([original magnification is indicated for all panels] X 10). b. Villous agglutination: clusters of degenerating distal villi are adherent to one another and focally enmeshed in fibrin (X . 4 c. Distal villous hypoplasia: a long, thin, non-branching stem villus is surrounded by a markedly reduced number of small hypoplastic distal villi (X .(10 d. Increased intervillous fibrin: stem villi are surrounded by a mantle of fibrin-type fibrinoid that does not extend to distal villi at the center of the lobule (X . (2 e. Nodular intervillous (and intravillous) fibrin: small aggregates of intervillous fibrin adhere to, and are focally reepithelialized by, distal villous trophoblast (X 20). f. Increased intervillous fibrin with intermediate trophoblast (X-cells): stem and distal villi are enmeshed in a matrix of fibrin and fibrinoid containing prominent intermediate trophoblast (arrowhead) (X . (10 From: Redline RW, et al. Maternal vascular underperfusion: nosology and reproducibility of placental reaction patterns. Pediatr Dev Pathol. 2004;7(3):237-49. With permission. 


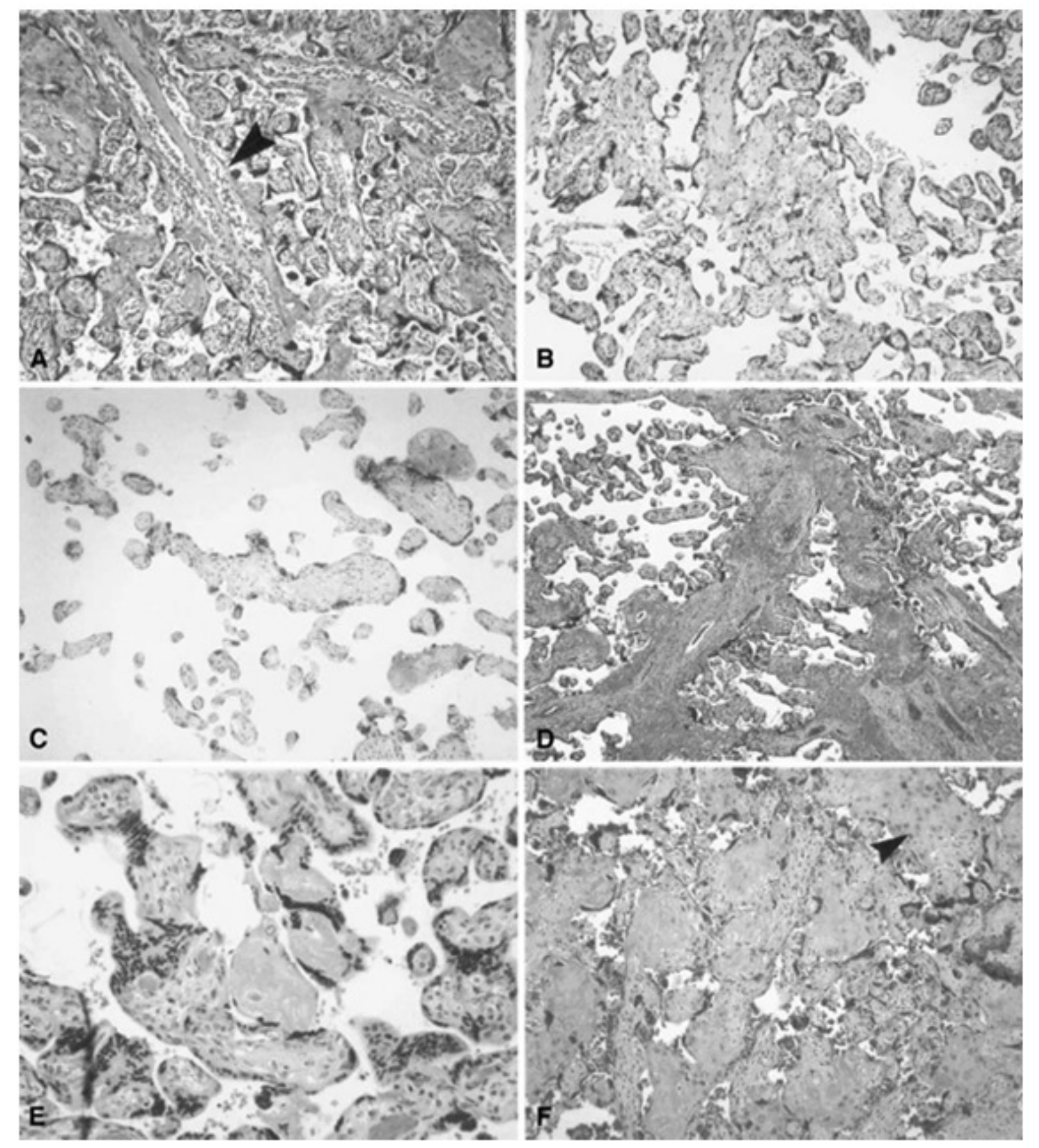




\section{Figure 6 (on next page)}

Figure 6

Amniotic fluid tissue factor concentration among women with normal pregnancies (median $3710.4 \mathrm{pg} / \mathrm{ml}$, range 2198.8-6268) and patients with a fetal demise (median $8535.4 \mathrm{pg} / \mathrm{ml}$, range 2208.2-125,990.0); (b) Amniotic fluid tissue factor activity among women with normal pregnancies (median $28.4 \mathrm{pM}$, range 10.2-84.9) and patients with a fetal demise (median 81.6 pM, range 7.2-1603.4). From Erez O, Gotsch F, Mazaki-Tovi S, et al. Evidence of maternal platelet activation, excessive thrombin generation, and high amniotic fluid tissue factor immunoreactivity and functional activity in patients with fetal death. J Matern Fetal Neonatal Med 2009;22:672-87, with permission. 

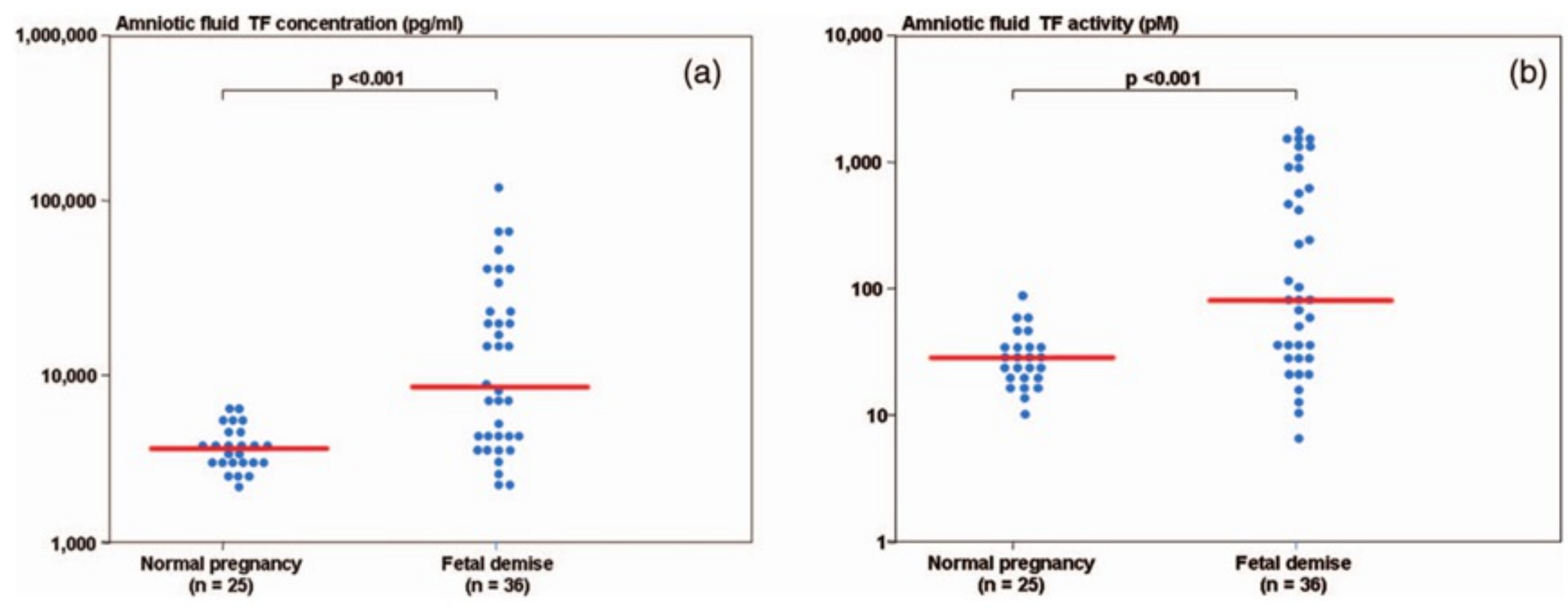
Figure 7 (on next page)

Figure 7

Maternal plasma TAT III concentration in women with preterm labor (PTL) and those with a Normal pregnancy (From Chaiworapongsa T, Espinoza J, Yoshimatsu J, Kim YM, Bujold E, Edwin S, et al. Activation of coagulation system in preterm labor and preterm premature rupture of membranes. J Matern Fetal Neonatal Med 2002 11(6):368-373, with permission). 


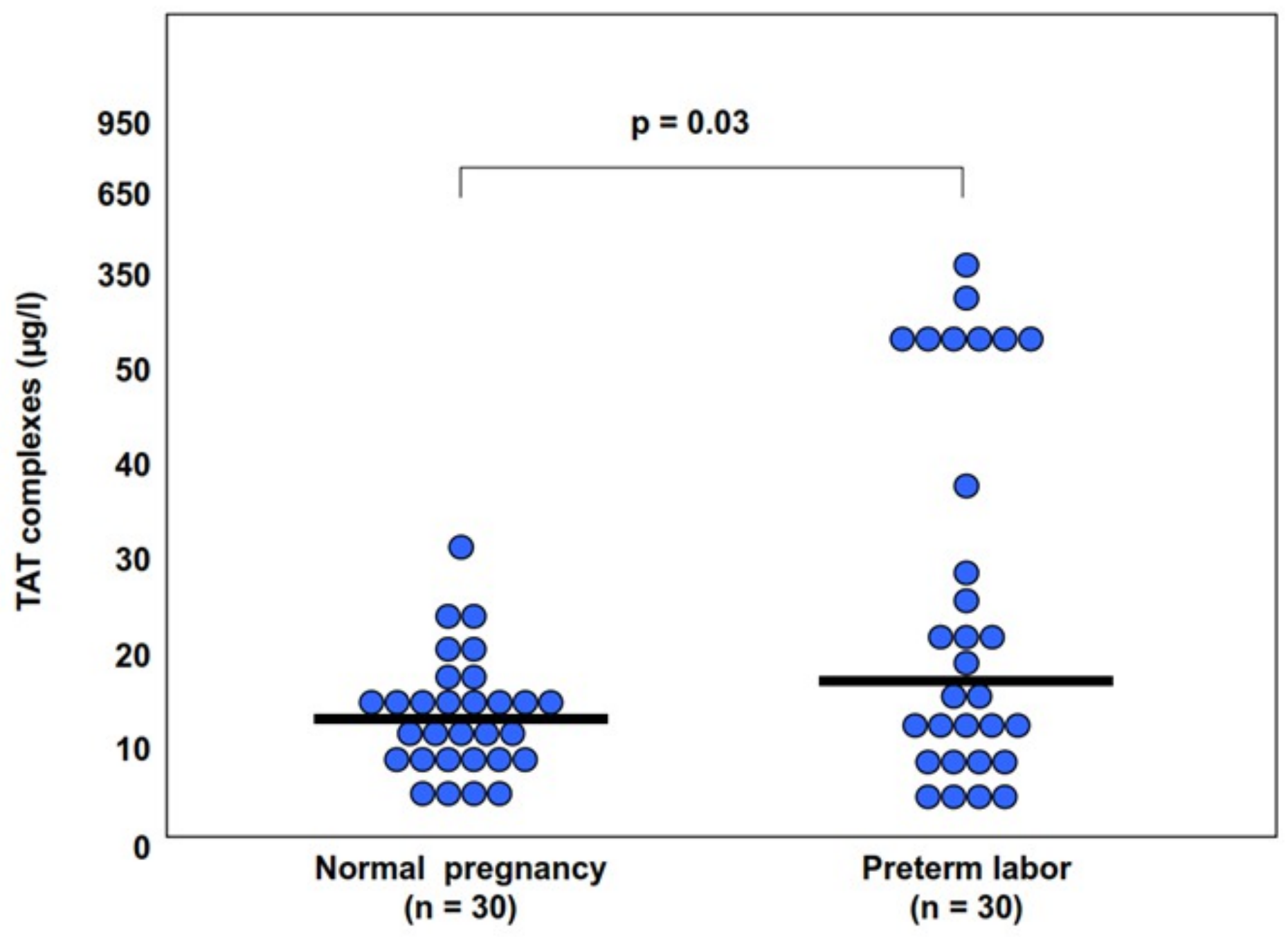

